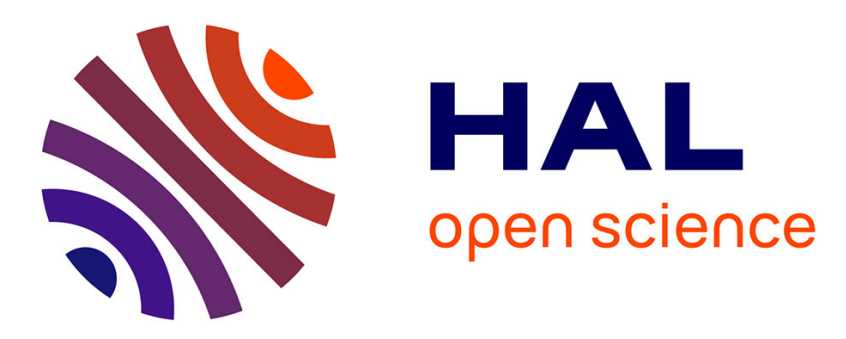

\title{
Practices and demands in retrofitting of vernacular rammed earth houses
}

Alejandro Buzo, Hyeon Jeong Cho, Léa Génis, Grégoire Paccoud

\section{To cite this version:}

Alejandro Buzo, Hyeon Jeong Cho, Léa Génis, Grégoire Paccoud. Practices and demands in retrofitting of vernacular rammed earth houses. International Conference on Vernacular Heritage, Sustainability and Earthen Architecture. VerSus 2014 | 2nd MEDITERRA | 2nd ResTAPIA, UNIVERSITAT POLITÈCNICA DE VALÈNCIA (SPAIN), Sep 2014, Valencia, Spain. pp.61-66. hal01234451

\section{HAL Id: hal-01234451 \\ https://hal.science/hal-01234451}

Submitted on 26 Nov 2015

HAL is a multi-disciplinary open access archive for the deposit and dissemination of scientific research documents, whether they are published or not. The documents may come from teaching and research institutions in France or abroad, or from public or private research centers.
L'archive ouverte pluridisciplinaire HAL, est destinée au dépôt et à la diffusion de documents scientifiques de niveau recherche, publiés ou non, émanant des établissements d'enseignement et de recherche français ou étrangers, des laboratoires publics ou privés. 


\title{
Practices and demands in retrofitting of vernacular rammed earth houses
}

\author{
A. Buzo \& H. J. Cho \\ DSA Architectures de Terre, CRATerre, Grenoble, France
}

L. Genis \& G. Paccoud

AE\&CC-CRAterre-ENSAG Research Unit, National Superior School of Architecture of Grenoble, France

\begin{abstract}
Numerous vernacular rammed earth buildings are today submitted to energetic regulations, especially thermal norms, and contemporary comfort requirements. In such a changing context, the ability to preserve and maintain this rammed earth heritage is questioned. Based on field studies results, the paper exposes the current practices and stakes concerning rammed earth heritage retrofitting in Dombes area, north of Lyon, France. It shows how cultures of building and of inhabiting (household profiles, retrofitting practices and processes, information gathering) can be related to energy efficiency, so as to better preserve heritage quality and to address heritage retrofitting on a wider scale.
\end{abstract}

\section{INTRODUCTION}

The ability to preserve and maintain rammed earth heritage is questioned in Rhône-Alpes region, although hundreds of thousand rammed earth buildings from the 19th and 20th centuries form an important part of the region's cultural heritage (Doat et. al. 1985, Le Tiec and Paccoud 2006). If the thermal properties of rammed earth are recognized by its inhabitants in the first place, the evolution of requirements in building's energy efficiency leads this heritage to energetic retrofitting. Examples of collapse and damages show the potential danger of bad practices in retrofitting rammed earth. However, the knowledge and know-how of the specificities involved by working with earth material remain distant to many. A study localized in a Rhône-Alpes community of cities permitted to explore the existing practices to understand the pressure put on thermal performances. Current issues in ancient building's retrofitting will be covered in a first part, followed by the objectives and methodology for the study. The results will then be presented and discussed.

\section{CURRENT ISSUES IN ANCIENT BUILDINGS' RETROFITTING}

\subsection{Energetic approach in retrofitting}

Considering it represents more than one third of existing buildings, ancient houses retrofitting is an essential issue at the European level. Energy retrofitting of rammed earth houses has been intensively studied during the last decade (Allinson \& Hall 2010,
Faria et al 2012, Beckett \& Ciancio 2013). However, it often undergoes technical and social issues that go beyond the lone standards compliance (Debizet 2010). Assessment procedures of energetic performance are hardly adapted with the complexity of ancient building (Meeddm 2010). Ancient rammed earth houses are moreover often inhabited and refurbished by private individuals. Before considering energetic performance, the buildings are thus already submitted to an imperative of comfort for simple questions of inhabitability (Berdoulay \& Soubeyran 2002). They are eventually bearing "heritage" values, anchored in history, culture and identity, characteristic of the evolution of rural areas in the last decades (Chevallier 2000).

Although the current regulation in France requires minimal insulation when retrofitting existing buildings $\mathrm{s}^{\mathrm{i}}$, those ancient buildings with massive walls remain exempted as their hygrothermal behavior wasn't known well enough when the law was adopted. Even so, it is a frequent concern for inhabitants and owners of old buildings: recurrent national and local awareness campaigns are stressing the need of insulating homes to save energy. These campaigns also promote global approach for the insulation process, when financial backing programs allow both global and step by step implementations.

\subsection{Social practices of ancient rammed earth houses}

This uncertain situation often leads house owners to undertake themselves refurbishment works (Charlier 2012). Some actors (inhabitants, craftsmen, profes- 
sionals, architects), who experiment and put up rammed earth buildings in everyday life, are advocating the right to live in link with exterior climate, in opposition with ambient standardization (Amsler 2012). However, ancient buildings sensitivity may render the interventions ineffective, if not dangerous, if some rules are not respected (Le Tiec \& Paccoud 2006, Levy 2010). Studies concerning energy retrofitting emphasize the need to apprehend context diversity, so as to better target retrofitting situations and question the implementation strategies (Prebat \& Puca 2013). In parallel, the literature in human sciences focus mainly on questions related to energy consumption in housing, in a quantitative perspective brought by socio-economic studies (Lutzenhizer 1993) and sociology of innovation (Zelem 2010). The interest to focus on the expression of actors practices during the renovation process is however recognized (Crosbie 2006, Subrémon 2010).

\subsection{Energy retrofitting in Dombes area}

These theoretical issues can be questioned when applied at the local scale. Indeed, the numerous old rammed earth buildings in Dombes area, north of Lyon are no exception to the rule, and are today submitted to energetic regulations, especially thermal norms, and contemporary comfort requirements. The issue was put forward by a community of cities in that area when its call for contributions was answered by a local association interested in local heritage. Their proposal was entitled "preserving and promoting the values of our built heritage considering the new building norms and our contemporary needs, especially those linked to energy savings". The study that is presented here is a part of the response to this call, and was led by the Association Saint Guignefort and CRAterre-ENSAG Laboratory, with the help of DSA-Terre students.

The aim of this paper is to present the study realized from that demand, and how it helped us showing to which extend energy retrofitting does imply more than technical answers. In this respect, a better understanding of the inhabitants and their retrofitting practices, as well as the reasons driving them in the retrofitting process are essential.

\section{OBJECTIVES AND METHOLOGY}

\subsection{Communauté de communes Chalaronne-Centre, in between ancient heritage and reconfiguration for rural spaces}

The field study has been realized during the last months of 2013 in a French rural district offering a wealth of dispersed rammed earth buildings: Communauté de communes Chalaronne-centre, in Dombes area (Figure1).

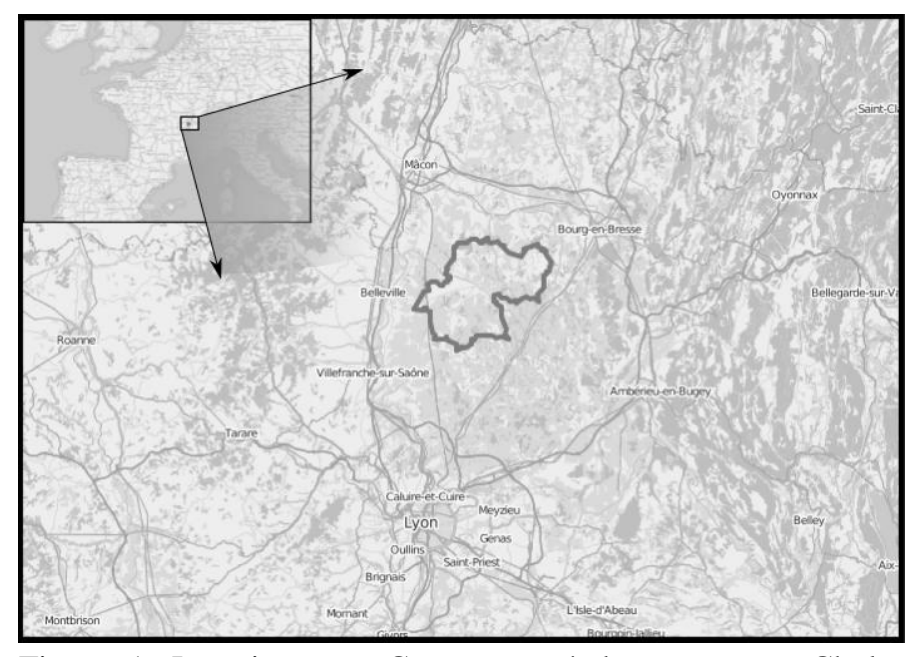

Figure 1. Location map-Communauté de communes Chalaronnes Centre, Ain, France. Credits: CRAterre-G. PaccoudOpenStreetMaps.

Dombes is a wet zone, where old marshes were turned into a complex of ponds centuries ago. The originality of this area is based on its land tenure, formed of large domains rooted on fish farming and hunting. In the area, housing used to be structured around dispersed farms built on small hills, wherever possible far from flood prone areas and damps. The soil is fine with almost no stone, sometimes clayish but mainly silty. Earth is one of the unique building materials available. It produces a fine yellowish rammed earth. Most of the time, the walls are supported by one meter basement made of pebbles that were harvested in the fields by the builders. Those stones were most of the time laid in "opus spicatum", "ear of wheat" or "fish bone", sometimes separated by horizontal brick layers (carons). Often inhabited by farmers, those houses are today being re-appropriated by new owners, urban workers who invest in this rural area (Manceron 2006).

The area presents one of the highest energy consumption in Rhône-Alpes region. The last studies raise the point that parts of this consumption can be explained by the high proportion of ancient houses whose owners do not have the capacity for thermal renovation (Meyer, 2012).

\subsection{Survey Process}

The methodology used to collect data was based on two main qualitative tools according to the sociotechnical approach:

- Socio-anthropological semi-directive interviews, life and retrofitting project accounts, sociodemographic data, way of life, insulation, consumption, comfort level, heritage appropriation;

- Technical surveys of surroundings and buildings, history of retrofitting projects, energy use estimates. A qualitative sample was built to be representative of both the buildings of the area and the period and methods of renovation. 23 owners and buildings were surveyed. 


\subsection{Aims of the study}

The aim of this data collection was to describe the interventions made on these buildings, especially in terms of energetic retrofitting: typologies, materials, intervention types and schedules, upkeep condition and renovation level, etc. A special attention was paid to a detailed understanding of the reasons of their interventions, their consequences in terms of energy consumption and comfort, but also in technical terms and inhabitants' representations.

\section{RESULTS}

The analysis of the qualitative sample showed at first glance the interest to focus on a wider scale on building cultures when considering rammed earth heritage retrofitting current practices and stakes.

Indeed, the comparison of the consumption per square meter of each case studied shows that the highest energy consumption is 2.5 higher than the lowest. Most of the cases are above the national mean, although half are very close to it. The relevant examples have homogeneous characteristics. It seems thus difficult to understand this data without entering deeper into the local cultures of building and inhabiting ancient houses.

\subsection{Evolutions of lifestyles and space management}

The demographic restructuring of rural areas (Chevallier 2000) are well represented in the sample. The evolution from familial farm owned houses and land towards a new model of rural life impacts the evolution of houses appropriation. Rural Dombes houses, conceived to shelter big families and communities (typically family and farm workers), are today inhabited by much smaller families. Most common profiles count two to three people, average-aged couples whose children have left home.

Moreover, the use of the buildings as permanent habitat for non-farmer residents fosters the differentiation in spaces management (Figure 2). The search for big volumes, spaces and comfort inside the house lead to the spread of two levels spaces distribution, and to an increase of inhabited space at the cost of intermediate spaces. Those were previously associated to the thermal envelope such as, for example, an attic full of straw and grain. In the same direction we observed a tendency to create and enlarge openings to provide wider and brighter spaces.

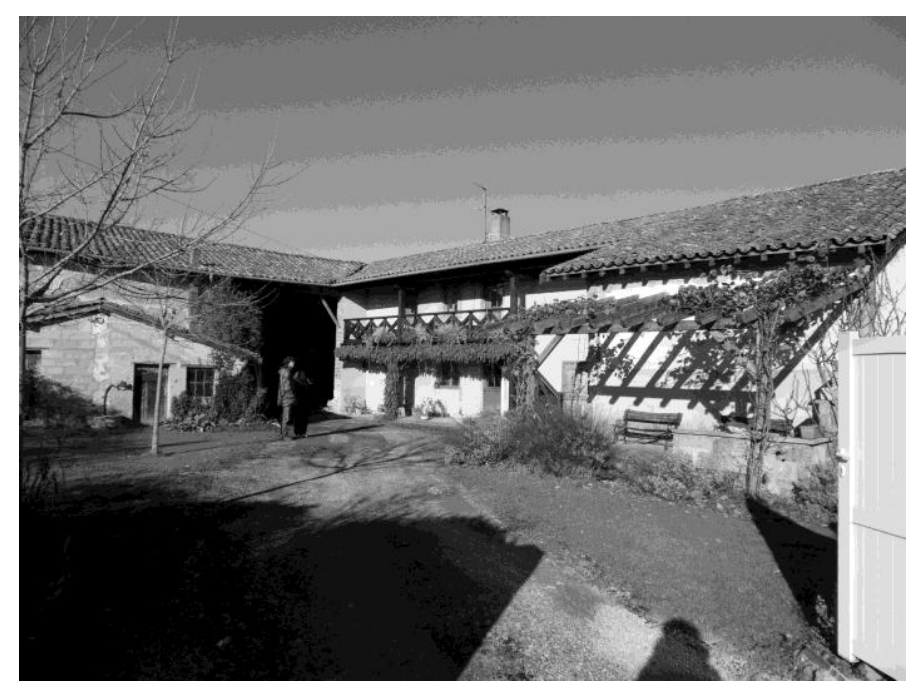

Figure 2. One of the rural Dombes houses from the sample. Credits: CRAterre - H.J. Cho

The changes in the inhabitants' profiles seem then to be linked to an evolution of the social representation of rammed earth houses and farms. Inhabitants' housing trajectory show that rammed earth houses are often associated with atmosphere representation, distinctive of the research of an "ancient" farm. It should then be "isolated", "calm", offer "spaces" and "volumes". The owners develop a reflective thinking on the project management, so as to rebuild the ancient house according to the spatial representation it has on "tradition" or "territory", (Ruegg 2011).

The increase of spaces and the decrease of inhabitants lead to heat up bigger and less occupied spaces. The tendency observed in the survey (Figure 3 ) is that the energy use per inhabitant increases with the size of the heated space per inhabitant, even if it is clear that other factors contribute strongly to the overall performance. How then to reconcile the aspiration of space and volume with the expectations of energetic efficiency?

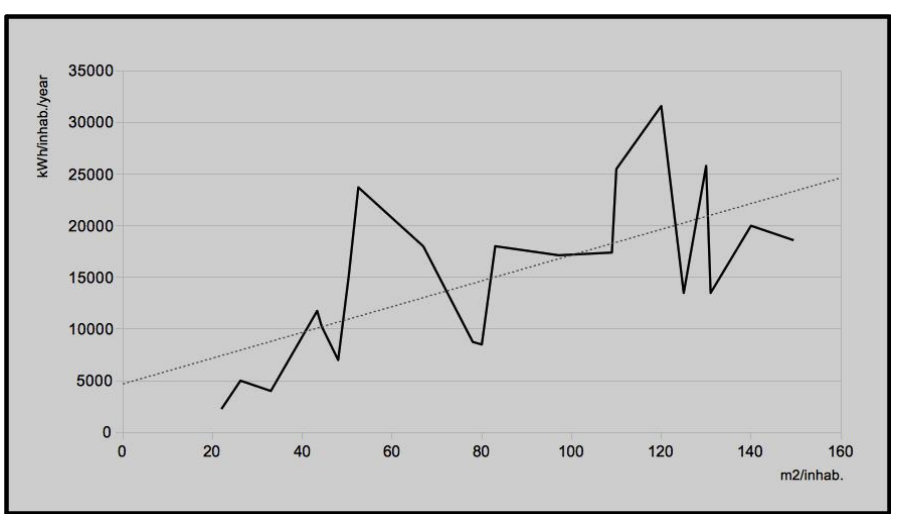

Figure 3. Energy consumption and floor surface per inhabitant Credits: CRAterre - G. Paccoud 
Some architectural options can help mitigating thermal requirements such as a conception using buffer spaces between outside and heated spaces, in a form of renewal of vernacular principles. As the volumes required increase, the space available to design with these buffer spaces is reduced: they are converted into living and heated spaces. Apart from a revision of the space and volumes requirements, which seems to be the easiest solution, technical solutions are promoted since the 80 ', especially the insulation of the building envelope.

\subsection{Evolution of the technical systems linked with an increased energetic performance}

\subsubsection{Insulation process}

Focusing on the insulation process showed that people who realized a full insulation of their house at once (floor, walls and roofs) were consuming less energy than those who insulated gradually.

The difference is mainly caused by an uncompleted insulation (e.g. only the roof was insulated). However, the overall thermal performance can be reduced by insulation differentials and thermal bridges between gradually insulated zones. Iterative modifications of the inhabited building usually leads to complex configurations of walls with connections between different structural and insulating materials, prone to thermal bridges especially when no global thermal project was designed.

The choice between global and gradual insulation design and implementation has to be placed within the process of getting into an existing building to be better understood. The survey showed that the priority can be to focus on the living spaces first (rooms, bathroom, kitchen), before even considering insulation. It might be difficult then to conceive and realize a global insulation, as both conception process and budget are constrained by the works already done. Global insulation of rural buildings can indeed be a significant investment, especially for such big ones as farms, and it seems it's seldom the chosen path.

Furthermore, the current regulation in France applying to such housing ${ }^{\mathrm{ii}}$, provides minimum performance requirements for elements and not for the global project, thus encouraging this step by step approach. Financial support programs for energetic performance improvement also refer to elements, but increased amounts are possible for packages of works, which tends to promote a global approach. As budget is often too tight for a full insulation, parts only will be insulated: either entire elements (roof, wall) as required by the standards, or simply rooms when outside of the standards' range. However, this regulation doesn't apply to rammed earth walls as their hygrothermal behavior and the associated risks are still a research topic (Dglan 2013, Heitz 2014, Miget 2012).
Technical recommendations for rammed earth insulation, although existing, remain very limited and advice provided can also be to avoid insulation. The lack of a global insulation is therefore not only a matter of limited money or too big project for one's capacity, but also of limited access to information or choice not to insulate the walls. Other interventions such as roof insulation, openings and heating systems upgrade and installation of ventilation systems are referred to when it comes to reduce energy consumption and improve inner comfort and design a global thermal project.

\subsubsection{Material used}

Some walls were nonetheless declared to be insulated in the surveyed buildings. The main technical solution observed in this respect is drywall. This technical solution promoted since the $80^{\prime}$ ' is still the reference system today for internal insulation. The plasterboard can be complemented with internal insulation but many times is left with a simple still air space between plasterboard and wall. The advantages of the solution as identified by the inhabitants interviewed are esthetic: it straightens up the walls and is referred to with words such as "straight", "clean" or "achieved".

However, both cases are hardly compliant with the hygrometric behavior of rammed earth. Still air will hinder moisture transfers within the wall and lead to water condensation and mould growth inside the cavity, sometimes towards the inner wall. Insulation materials commonly found present a limited lifespan, especially with earthen walls: moisture, water, rodents and insects damages glasswool, the most common insulating materials used. Polystyrene and other foams, also used as insulation materials for these drywall systems, are not allowing the continuity of the moisture transfers within walls and can lead to a dangerous accumulation of moisture in the rammed earth. Such insulation practices consider ancient buildings the same way as conventional construction and can have harmful consequences on the building, ultimately the collapse of the considered wall 5 to 10 years after the change in hygrometric mode caused by the works (Heitz 2014)

\subsubsection{Energy source}

The focus on energy use is also prevalent when considering energetic performance of the buildings. It was then interesting to notice that the specificity of the earth material was barely taken into account when choosing the type of heating system: radiant or convection heating is not differentiated. The dominant factor remains the energy cost. It brings us to consider the motivation for energy saving in buildings, which seems more linked with an imperative to save money than towards an ideal of "environmentally friendly energy saving” (Nemoz, 2011). 
For example, the choice of heating fuel used to be prevalent because of its lower price, with relatively low cost boilers. Today, with the increase in the price of heating fuel, the trend is to use the heating fuel boilers as an extra heating system. Thus, we can notice that, apart from the ones who buy their wood (they generally have average energy consumption levels), some inhabitants do have a free access to that resource. They're generally farmers, and have among the highest energy consumption level in this study. These farmers own their house and surrounding lands where they work and get wood. As long as the access to wood is almost free, they don't need to improve their energy efficiency and their heating system to save money.

This data show that, of course, energy performance is correlated with the technical works done on the buildings (in terms of space, insulation, or choice of material) and the choice of energy source. However, is energetic performance only linked to the technical capacities of the building? Are the potential savings relying on technical choices only?

\section{QUESTIONS RAISED BY THE REFURBISHMENT PROCESS AND NEEDS}

"What to expect from the inhabitants we are, taken between ecological good will and comfort expectations, between heating problems and savings worry, between "household reasons" and technical directions?". Subremon (2011) raises here the dilemmas that concern any individual when involved today in a renovation process. The interest for the energetic issues leads to question the whole renovation process: energy issues cannot be dealt with alone, neither at the beginning nor at the end of the process.

\subsection{The dilemmas of "good practices"}

The aspects mentioned above (changing heating systems, focusing on complete house insulation) are well known in terms of technical features. They are covered in most of the sensitization materials produced and prescribed by norms, rules and good practices as "good ways" to save energy. It gets however problematic when considering the choices that any household has to make concerning energy retrofitting, and even more challenging when considering the specific case of ancient rammed earth buildings.

Hence, implementation of "good practices" in energy retrofitting often represents a substantial financial investment. The stakeholders appear to be more and more informed, even sensitized to the use of materials considered as "healthy" and "natural", but also to the functioning of rammed earth buildings in terms of "hygrometry" or "breathability". A common stance among the persons encountered was that it was "important to let the wall breathe". However, this does not always imply a change in practices which are linked to other stakes and causes, such as money. The point in a renovation is often to decide where to invest: it implies reaching compromises between one's issues and wills. The project process implies then to keep the capacity to reassess, to change ones' mind when encountering a problematic issue. Instead of pressing into compromise between insulation materials, architectural aspects can also be taken into account, looking for solutions in space modularity or in staged implementation of a global project.

\subsection{Act in an uncertain world}

One more issue eventually occurs when facing the lack of widespread technical and normative reference concerning the thermal performance of rammed earth, and the potential for insulation. Homeowners have to find their way in the middle of different opinions, taking advice where they can find it to finally find what they consider being the "good information". In that uncertain world (Callon 2001), where even the professionals do not agree on the good practices, the social capital is important, and will determine the solutions that enter in one's landscape of possibilities. It leads to strategies of selfinformation whose results can often be difficult to measure.

Data research often starts with preliminary information gathering in a close relation circle (family, friends, local professionals...) to spread afterwards to specialized organizations. This advice-taking process aims at establishing a first diagnosis, to know towards which practices to turn. However, the information collected often lacks details, and makes it difficult to find accurate solutions for one's specific situation. Independent diagnosis can answer that need but it is costly. On the other hand it can be difficult to get specific information from specialized and official structures that provide general directions and are in a tricky situation when it comes to recommend artisans or other professionals. The lack of a specific information desk dedicated to rammed earth retrofitting is often pointed out.

\section{CONCLUSION}

The complex stances that came out from the field study brought us to face multiple facets of the buildings and inhabitant's trajectories. A complex and interwoven fabric of specific characteristics comes out, hardly compatible with the idea of uniformity conveyed by norms. It shows how spaces appropriation, heating and insulation systems or project processes are elements to be considered to propose adapted solutions for the ancient buildings and those who live daily in it. 
Ensuring an outstanding thermal performance with the currently encouraged technical solutions is not obvious. It implies a global conception of the retrofitting project, limited modifications during the process and a global implementation. The study realized didn't come across such process fully implemented, and examples of external insulation aren't common. This supports the idea that these conditions are rather unusual in retrofitting projects, and possibly contrary to the motivations of old buildings' owners who undertake a retrofitting project. Furthermore, global implementation remains expensive enough to drive people away even if they are willing to consider it.

Eventually, it seems essential to think about how to better consider energy efficiency of the old buildings, including economic, environmental and social aspects and not only technical. Some proposals could be:

- Sensitize on the impacts of renovation on the building structure. It could use new indicators for energy efficiency to promote self-responsibility on energy consumptions, g.e. kwh/inhab/year instead of $\mathrm{kwh} / \mathrm{sqm} /$ year

- Produce reference documentation about intervention on earthen buildings

- Make specialized advice affordable/available, which implies a political will as well as dedicated organization(s).

Such advice should realize the importance of a global thermal conception for the projects, integrating phasing of works and potential for evolution of the spaces. Its implementation calls upon architectural competences to complement today's engineer approaches.

\section{REFERENCES}

Ademe. 2013. Rénovation énergétique. Habitat naturel, 50. Montgeron: Armada Concepts.

Allinson, D. \& Hall, M. 2010. Hygrothermal analysis of a stabilised rammed earth test building in the UK. Energy and Buildings, 42(6) : 845-852.

Beckett, C. \& Ciancio, D. 2012. A review of the contribution of thermal mass to thermal comfort in rammed earth structures. 2nd International Conference on Sustainable Built Environment. Sri Lanka.

Berdoulay, V. \& Soubeyran, O. 2002. L'écologie urbaine et l'urbanisme, aux fondements des enjeux actuels. Paris: La Découverte.

Callon, M., Lascoumes, P. \& Barthe, Y. 2001. Agir dans un monde incertain, essai sur la démocratie technique. Paris: Ed. du Seuil.

Charlier, D. 2012. Les déterminants des investissements économiseurs d'énergie dans le secteur résidentiel en France. Grenoble: Presses de l'Université de Grenoble.

Chevallier, D. 2000. Vives campagnes: le patrimoine rural, projet de soc . Paris: Éd. Autrement.
Crosbie, T. 2006. Household energy studies: the gap between theory and method. Energy \& Environment, 17 (5): 735753.

Devron, J.-F. 2012. Energétique du patrimoine, des matériaux innovants pour la rénovation. D'architectures, le magazine professionnel de la création architectura, 207 : 33-64.

Dglan (Direction générale de l'Aménagement, logement et nature) (ed.), CETE Est, LRA, LMDC \& MPF. 2013. HYGROBA. Fonctionnement Hygrométrique du bâti ancien. Paris: Ministère de l'écologie, du développement durable et de l'environnement.

Doat, P. \& Centre de recherche et d'application pour la construction en terre. 1985. Construire en terre. Paris: Éditions Alternative.

Faria, P., Silva, V., Pereira, C. \& Rocha, M. 2012. The monitoring of rammed earth experimental walls and characterization of rammed earth samples. Rammed Earth Conservation : 91-97.

Heitz, P. 2014. Architecture en terre - La pathologie humide du pisé. Revue Qualité Construction, 143 : 62-66.

Le Tiec, J.-M. \& Paccoud, G. 2006. Pisé H2O. De l'eau et des grains pour un renouveau du pisé en Rhône-Alpes. Villefontaine: CRAterre Editions.

Lévy, P. 2010.

$n-$ taux (Vols. 1-1). Mens, France: Terre vivante.

Lutzenhizer, L. 1993. "Social and Behavioral Aspects of Energy use". Annual Review of Energy and the Environment, 18 (1) : 247-289.

Manceron, V., 2006. Le pays de Dombes et ses mises en image: jeu sur les frontières et quête de reconnaissance. Ruralia. Sciences sociales et mondes ruraux contemporains. http://ruralia.revues.org/1261.

Miget, S. 2012. Isoler un mur en pisé, une hérésie ? Le moniteur. 23/05/2012. http://www.lemoniteur.fr/183-recherchedeveloppement/article/actualite/17623527-isoler-un-muren-pise-une-heresie.

Meeddm \& Maisons paysannes de France (dir.) 2010. ATHEBA, Amélioration Thermique du bâti ancien. Paris: Ministère de l'écologie, du développement durable et de l'environnement.

Prebat \& Puca (dir.). 2013. Réduire la précarité énergétique. Colloque organisé dans le cadre des « rencontres du PREBAT », le 23 mai 2013. Ecole Nationale Supérieure d'Architecture Paris-Belleville.

Ruegg, F., 2011. La maison paysanne: histoire d'un mythe, Collection Archigraphy. Poche. Infolio, Gollion, Suisse.

Subrémon, H .(dir.). 2010. État de la littérature anthropologique sur la consommation d'énergie domestique en particulier de chauffage. Charenton-le-Pont: CNRS, Laboratoire Architecture urbanisme sociétés.

Zélem, M.-C. 2010. Politiques de mai

cio-anthropologique (Vols. 1-1). Paris: L'Harmattan.

\footnotetext{
${ }^{\mathrm{i}}$ Décret n²007-363 du 19 mars 2007

${ }^{i i}$ Ibid.
} 